\title{
Hepcidin Expression in Adipose Tissue Increases during Cardiac Surgery
}

\author{
M. VOKURKA ${ }^{1}$, Z. LACINOVÁ ${ }^{2}$, J. KŘEMEN ${ }^{2}$, P. KOPECKÝ ${ }^{3}$, J. BLÁHA $^{3}$, \\ K. PELINKOVÁ ${ }^{4}$, M. HALUZÍK ${ }^{2}$, E. NEČAS ${ }^{1}$ \\ ${ }^{1}$ Institute of Pathological Physiology and Center of Experimental Hematology, ${ }^{2}$ Third Department \\ of Internal Medicine, ${ }^{3}$ Department of Anesthesiology, Resuscitation and Intensive Medicine, \\ ${ }^{4}$ Institute of Clinical Chemistry and Laboratory Medicine, Charles University in Prague, First \\ Faculty of Medicine and General Teaching Hospital, Prague, Czech Republic
}

Received February 4, 2009

Accepted July 2, 2009

On-line August 12, 2009

\section{Summary}

Hepcidin, a key regulator of iron metabolism, plays a crucial role in the pathogenesis of anemia of chronic disease. Although it is produced mainly in the liver, its recently described expression in adipose tissue has been shown to be enhanced in massive obesity due to chronic low-grade inflammation. Our objective was to study the changes in hepcidin expression in adipose tissue during acute-phase reaction. We measured hepcidin mRNA expression from isolated subcutaneous and epicardial adipose tissue at the beginning and at the end of the surgery. The expression of mRNAs for hepcidin and other iron-related genes (transferrin receptor 1 , divalent metal transporter 1, ferritin, ferroportin) were measured by real-time RT-PCR. Hepcidin expression significantly increased at the end of the surgery in subcutaneous but not in epicardial adipose tissue. Apart from the increased levels of cytokines, the parameters of iron metabolism showed typical inflammation-induced changes. We suggest that acute inflammatory changes could affect the regulation of hepcidin expression in subcutaneous adipose tissue and thus possibly contribute to inflammation-induced systemic changes of iron metabolism.

\section{Key words}

Hepcidin • Adipose tissue • Iron • Inflammation • Surgery

\section{Corresponding author}

Martin Vokurka, Institute of Pathological Physiology, First Faculty of Medicine, Charles University in Prague, U Nemocnice 5, 12853 Prague, Czech Republic. Fax: +420224 912834 . E-mail: martin.vokurka@lf1.cuni.cz

\section{Introduction}

Inflammation is known to interfere with iron metabolism and erythropoiesis causing anemia of chronic disease (ACD) also known as anemia of inflammation (Weiss and Goodnough 2005, Adamson 2008). It accompanies inflammatory and autoimmune diseases, acute and chronic infections, malignancies, chronic kidney disease, but it can develop rapidly as anemia of critical illness (Corwin and Krantz 2000). Dysregulation of iron metabolism, iron sequestration in reticuloendothelial system and its limited availability for erythropoiesis contribute to the development of this anemia.

Hepcidin, a key regulator of iron metabolism, was shown to modulate iron distribution changes in ACD (Weinstein et al. 2002). It is a small peptide of 25 amino acids produced mainly by hepatocytes; it inhibits iron absorption in the duodenum and its release from macrophages (Ganz 2007). Its expression is stimulated by iron (Pigeon et al. 2001), anemia and hypoxia (Nicolas et al. 2002), erythropoiesis (Vokurka et al. 2006, Pak et al. 2006), and inflammation (Nicolas et al. 2002). Interleukin-6 (IL-6) was demonstrated as a powerful stimulator of hepcidin liver production and hepcidin is supposed to be a type II acute phase reactant (Nemeth et al. 2003). Molecular mechanisms of its regulation in the liver have been partially revealed (Kemna et al. 2008, Fleming 2008).

Recently, hepcidin expression in adipose tissue 
has been described and shown to be increased in patients with severe obesity (Bekri et al. 2006). This finding is in accordance with earlier studies that showed which adipose tissue of obese patients produced increased amount of proinflammatory cytokines contributing to the development of a low-grade systemic inflammation in these patients (Dandona et al. 2004). Adipose tissue is a very active endocrine organ secreting numerous hormones and cytokines associated with important systemic effects on different metabolic processes (Havel 2002, Haluzík et al. 2004). Moreover, obesity has been associated with low-serum iron concentrations (Wenzel et al. 1962), while the etiology of this hypoferremia is rather uncertain and it could probably be attributed to inflammation and the regulation of hepcidin expression (McClung and Karl 2009).

We have previously described increased expression of several proinflammatory factors in epicardial and subcutaneous adipose tissue of patients after elective cardiac surgery operation (Křemen et al. 2006). These adipokines may have systemic effects and contribute to the development of insulin resistance (Havel 2002). Here we tested the hypothesis that mRNA expression of hepcidin in adipose tissue can be changed during the surgery. To this end, we measured mRNA expression of hepcidin and other genes in subcutaneous and epicardial adipose tissue of patients at the beginning and at the end of elective cardiac surgery. We observed an increase of hepcidin expression in subcutaneous but not in epicardial adipose tissue after the surgery. We propose that adipose tissue could contribute to the systemic production of hepcidin in inflammatory conditions and in turn lead to the subsequent systemic changes of iron metabolism.

\section{Methods}

\section{Human study subjects}

Twelve patients from previously studied group 8 men and 4 women, mean age 60.5 years (39-81), mean body mass index $27.2 \mathrm{~kg} / \mathrm{m}^{2}$ (19.7-36.8) who underwent major elective cardiac surgery (aortocoronary bypass, valvular plastique) were included in this study (Křemen et al. 2006). None of the patients had malignant tumor, or acute infectious disease. The patients signed written informed consent. The study was approved by the Human Ethical Review Committee, First Medical Faculty, and General University Hospital, Prague, Czech Republic.

\section{Sampling and assays}

Blood samples were taken at basal state (before the start of anesthesia) and at the end of surgery. Samples of the subcutaneous and epicardial adipose tissue were taken at the beginning and before the end of surgery. Subcutaneous samples were taken from thoracic region and were immediately stored at $-70{ }^{\circ} \mathrm{C}$ in RNALater reagent (Qiagen, Hilden, Germany). The average time between the withdrawal of the sample at the beginning and at the end of surgery was $252 \pm 27 \mathrm{~min}$. Measurements of blood count and blood iron parameters (concentration of iron, transferrin, ferritin in serum and transferrin saturation) were done in routine biochemical laboratory by standard procedures. Determination of serum cytokines and RNA extraction from human adipose tissue and reverse transcription were described previously (Křemen et al. 2006).

\section{Real-time quantitative PCR}

mRNA expression levels of genes studied were determined by real-time PCR on a Roche LightCycler instrument, using LightCycler FastStart DNA Master SYBR Green I kit (Roche Diagnostics GmbH, Mannheim, Germany) as described previously (Vokurka et al. 2006). Primers were synthetized by Generi Biotech (Czech Republic). All analyses were carried out in triplicate. The increase of fluorescence was measured in real time, data were obtained as threshold cycle $\mathrm{C}_{\mathrm{T}}$ value. To correct for the different amounts of cDNA present in the sample at the start of the LightCycler run, the obtained crossing points for the target mRNAs were normalized to reference gene mRNA ( $\beta 2$-microglobulin): for each sample, the difference between target mRNA crossing point and reference gene mRNA crossing point was calculated, resulting in a reference gene normalized crossing point. The normalized crossing point for the sample from the end of the surgery was then subtracted from the normalized crossing point for the sample taken at the beginning, giving the final difference (n) in cycle numbers between the two samples. The values were obtained using $2^{\mathrm{n}}$ formula and represented as the amount of target mRNA relative to $\beta 2$-microglobulin.

\section{Statistical analysis}

Statistical analysis was performed on GraphPad Prism 4, the Shapiro-Wilk W test was used in testing for normality (STATISTICA Base, StatSoft). The results are expressed as means \pm S.E.M. Changes of hematological parameters in humans were evaluated using paired $t$-test, 
Table 1. Changes in hematological indices at the beginning (start) and before the end (end) of the surgery or the next day after $(*)$; $\mathrm{n}=12$.

\begin{tabular}{llll}
\hline & Start & End & p \\
\hline Hematocrit $(\%)$ & $42.0 \pm 1.0$ & $29.7 \pm 1.2^{*}$ & $<0.0001$ \\
Ferritin $(\mu \mathrm{g} / \mathrm{l})$ & $238 \pm 73$ & $372 \pm 52$ & 0.0486 \\
Serrum iron $(\mu \mathrm{mol} / \mathrm{l})$ & $12.5 \pm 1.4$ & $8.3 \pm 1.4$ & 0.0218 \\
Transferrin $(\mathrm{g} / \mathrm{l})$ & $1.97 \pm 0.10$ & $1.57 \pm 0.11$ & 0.0104 \\
Transferrin saturation $(\%)$ & $27.4 \pm 2.6$ & $25.8 \pm 5.6$ & $\mathrm{NS}$ \\
Interleukin-6 $(\mathrm{pg} / \mathrm{ml})$ & $7.62 \pm 4.20$ & $165.10 \pm 70.31$ & 0.002 \\
Tumor necrosis factor $\alpha(\mathrm{ng} / \mathrm{ml})$ & $1.88 \pm 0.47$ & $4.22 \pm 0.80$ & 0.02 \\
\hline
\end{tabular}

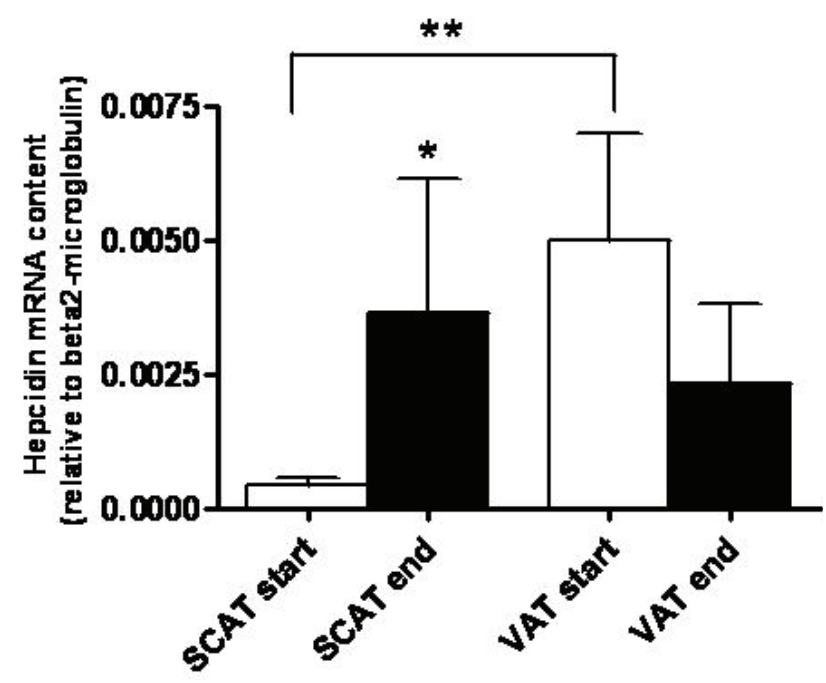

Fig. 1. Changes in hepcidin expression in adipose tissue at the beginning (start) and before the end of the surgery. SCAT subcutaneous, VAT - visceral (epicardial) adipose tissue. Data presented as mean \pm S.E.M. $* p<0.05 * * p<0.01$.

the expression of studied genes in human adipose tissue was evaluated by Wilcoxon matched pair test. Spearman correlation test was used for correlation coefficient calculations.

\section{Results}

Serum iron and inflammatory parameters in patients that underwent surgery

Iron metabolism parameters and proinflammatory cytokines (IL-6, tumor necrosis factor TNF $\alpha$ ) were measured in serum at the beginning and at the end of the surgery as well. While serum ferritin concentration increased after the surgical operation, the levels of serum iron and transferrin concentration decreased. However, there was no change in serum transferrin saturation. The concentrations of both IL-6 and TNF $\alpha$ increased (Table 1).

Changes of $m R N A$ expression of hepcidin and other ironrelated genes in adipose tissues at the beginning and at the end of the surgery

Baseline expression of hepcidin was higher in epicardial visceral adipose tissue (VAT) than the subcutaneous adipose tissue (SCAT). However, during the surgery, significant increase of hepcidin expression in SCAT was observed, while the changes in visceral tissue were not significant (Fig. 1).

Transferrin receptor 1 (TfR1) mRNA expression was comparable in both tissues before surgery, and increased in both tissues during the surgery. While initial basal ferroportin (FPN) mRNA expression was significantly higher in visceral tissue, significant decrease was observed in both adipose tissue depots after surgery. On the other hand, the mRNAs for divalent metal transporter 1 (DMT1) and ferritin did not change (Fig. 2).

Correlation of hepcidin expression with body mass index (BMI) and cytokines

Hepcidin mRNA expression was correlated with BMI and concentration and expression of several cytokines measured previously (Křemen et al. 2006). Hepcidin mRNA expression at the beginning of the surgical operation did not correlate with BMI either in subcutaneous, nor in epicardial adipose tissue. Hepcidin mRNA level in epicardial VAT correlated negatively with serum IL-6 and TNF $\alpha$ concentrations (Figs 3A and 3B). In subcutaneous but not epicardial adipose tissue it correlated positively with TNF $\alpha$ mRNA expression (Figs 3C and 3D). The other cytokines measured did not exert any significant correlation with hepcidin expression. 


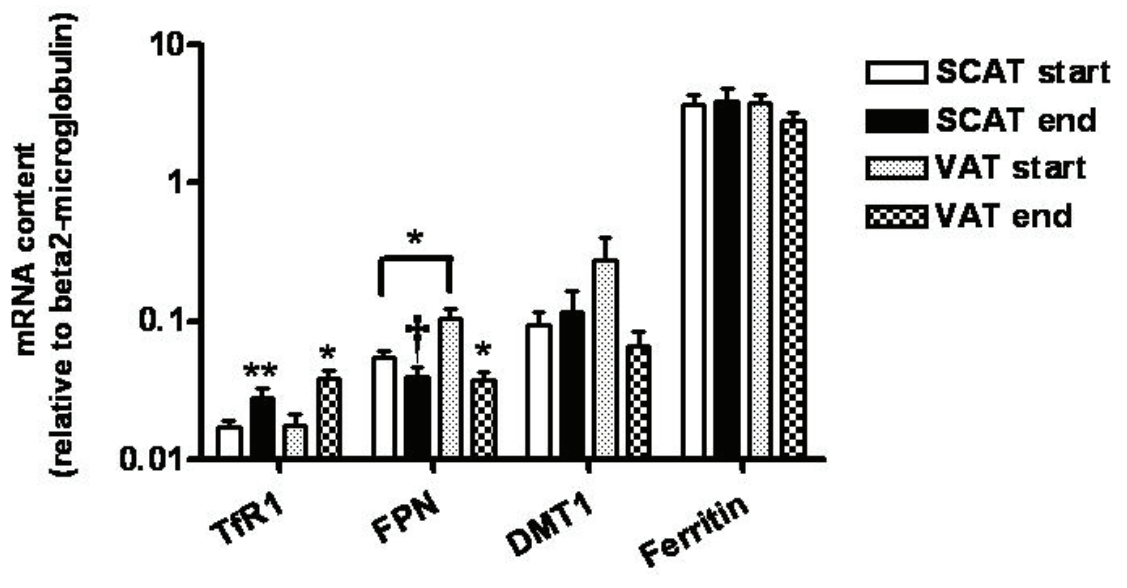

Fig. 2. Changes in iron metabolism genes expression in adipose tissue at the beginning (start) and before the end of the surgery. TfR1 - transferrin receptor 1, FPN - ferroportin, DMT1 divalent metal transporter 1. SCAT subcutane-ous, VAT - visceral (epicardial) adipose tissue. Data presented as mean \pm S.E.M. $* p<0.001 * * p<0.03+p<0.05$.

$$
\text { ") } r=-0.4943, p=0.0227
$$

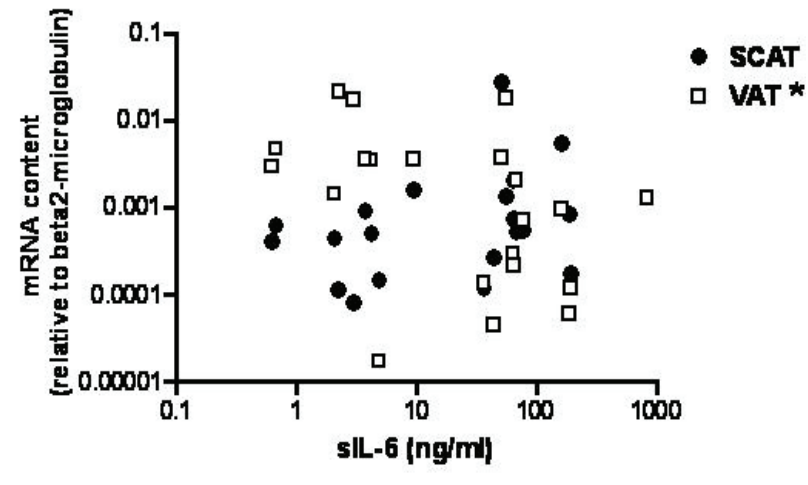

A

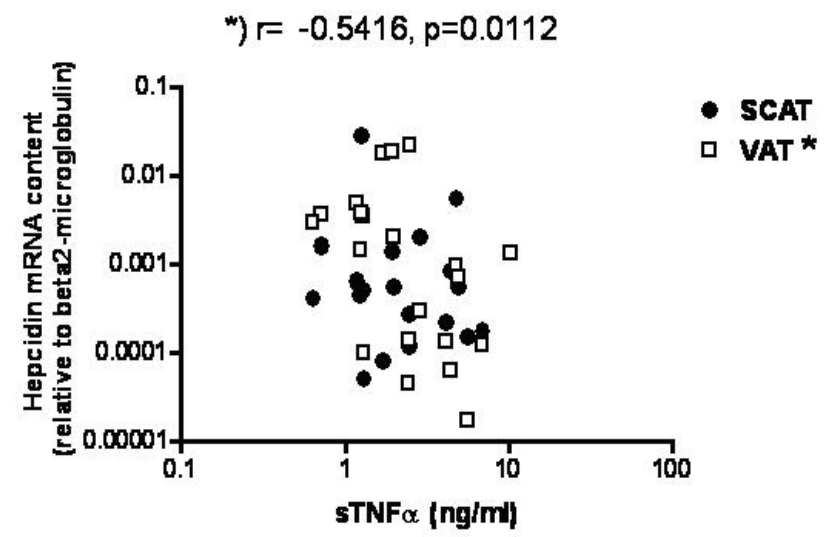

B
") $r=0.4407, p=0.0353$

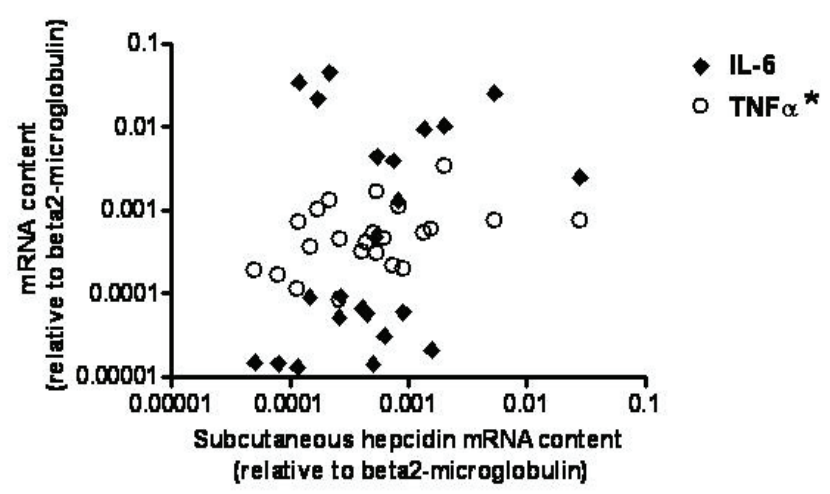

C

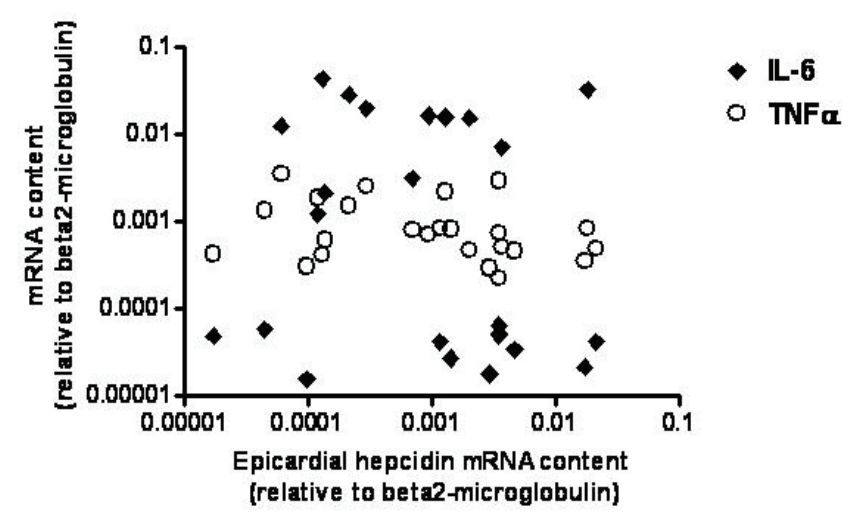

D

Fig. 3. Correlation between hepcidin mRNA expression and serum concentrations or mRNA expression of IL-6 and TNF $\alpha$. Correlation of serum concentrations of IL-6 - sIL-6 (A) and TNF $\alpha-$ sTNF $\alpha$ (B) to the mRNA levels of hepcidin (hepc) in subcutaneous (SCAT) and epicardial (visceral VAT) adipose tissue. Correlation of hepcidin expression in subcutaneous (C) and epicardial (D) adipose tissue with IL-6 and TNF $\alpha$ mRNA levels. 


\section{Discussion}

The present study demonstrated an increase of hepcidin mRNA expression in human subcutaneous adipose tissue after the major elective cardiac surgery. Hepcidin mRNA expression increases in subcutaneous but not epicardial adipose tissue after acute surgical procedure. It is the first demonstration of acute changes of hepcidin expression, and to our knowledge also the first demonstration of the changes of mRNA levels of several iron-related genes in the adipose tissue after surgery.

Hepcidin is a mediator of iron metabolism in anemia of chronic disease (Weinstein et al. 2002). ACD is a frequent immune driven anemia occurring in inflammations, infections, malignancies and acute critical illnesses. Routine hepcidin determination is not yet largely available and different methods including antibodies, mass spectrometry, mRNA measurement or determination of hepcidin precursor prohepcidin have been used to reveal its role in pathophysiology of various diseases (Kemna et al. 2008).

Recently, two reports described changes of hepcidin or prohepcidin serum concentration in acute heart surgery. Hoppe et al. (2009) described changes in iron metabolism and serum hepcidin concentration in patients after heart surgery. Increased serum concentrations of prohepcidin preceded that of hepcidin in the patients. Prohepcidin but not hepcidin was also measured during the large cardiac surgery in relation to IL-6 and other inflammatory parameters by Maruna et al. (2008). Prohepcidin level responded as a negative acute phase reactant during systemic inflammatory response associated with cardiac surgery.

The possible role of adipocytes in hepcidin production was first demonstrated by Bekri et al. (2006). Although hepcidin is mainly hepatocyte-derived peptide, its extrahepatic expression has been demonstrated in several other organs (Pigeon et al. 2001). Apart from adipose tissue, hepcidin expression has been shown in pancreas (Krijt et al. 2004), myocardium (Merle et al. 2007, Krijt et al. 2007), macrophages (Sow et al. 2007, Theurl et al. 2008), and pancreatic beta cells (Kulaksiz et al. 2008).

Hepcidin mRNA expression in these tissues is much lower than that in the liver and its possible significance is not clear and requires further investigation. Hepcidin could possibly exert some paracrine or autocrine functions or act locally as antimicrobial peptide if it reaches appropriate concentration locally. Hepcidin release from the adipose tissues, as well as cytokines and adipokines, could contribute significantly to the systemic concentrations because of the large mass of the tissue. However, this hypothesis needs further evaluation and the analysis of serum hepcidin levels.

In fact, several observations suggest the possible role of adipose tissue in controlling iron metabolism. Low-serum iron concentrations were observed in obese subjects (Wenzel et al. 1962). Recently, fat mass was described as a significant negative predictor of serum iron and this hypoferremia seemed not to be explained by differences in iron intake (Menzie et al. 2008). This could be due to iron deficiency anemia and due to inflammatory-mediated functional iron deficiency in ACD (Yanoff et al. 2007) which might be mediated by hepcidin. Overweight and obesity were associated with changes in iron metabolism parameters that would be expected to occur under the conditions of chronic systemic inflammation (Ausk and Ioannou 2008). Furthermore, adiposity in young women predicted not only lower iron absorption but also reduced response to iron supplementation, possibly due to increased hepcidin production (Zimmermann et al. 2008).

In insects, most antimicrobial peptides like hepcidin are synthesized in the fat body (Park et al. 2001), an organ analogous to the liver of vertebrates. The fat body of Drosophila incorporates the mammalian homologues of the liver and hematopoietic and immune systems (Sondergaard 1993), and is recognized also as the equivalent of mammalian adipose tissue (Tong et al. 2000). Defensin-like peptide drosomycin similar to hepcidin is synthesized in the fat body (Verga Falzacappa and Muckenthaler 2005). The liver and the adipose tissue thus maintained their developmental heritage sharing an architectural organization in which the metabolic cells are in close contact to immune cells, mainly macrophages, and to blood vessels (Hotamisligil 2006).

Apart from hepcidin production by adipose tissue, another possible interaction between adipose tissue, inflammation and hepcidin was suggested by Chung et al. (2007). Leptin, an important adipose tissuederived cytokine, induced hepcidin expression in human hepatoma cells. However, in the previous study we did not observe increased serum leptin concentration at the end of the surgery (Křemen et al. 2006).

The regulation of hepcidin in adipose tissue remains unknown and may be similar to other adipokines 
in subcutaneous and epicardial adipose tissues. Inflammation-induced hepcidin stimulation is mediated through IL-6/STAT3 pathway (Wrighting and Andrews 2006, Verga Falzacappa et al. 2007) which was described also in adipose tissue (Bendinelli et al. 2000) as well as LPS-induced expression of inflammatory cytokines (Creely et al. 2007). On the other hand, mRNA for hemojuvelin, a surface molecule important for iron sensing and hepcidin production in the liver (Lin et al. 2006), was not detected in adipose tissue in our experiments. Hepcidin expression in adipose tissue is thus stimulated rather by inflammatory stimuli than by iron. However, hepcidin expression in epicardial adipose tissue showed a negative correlation with serum IL-6 and TNF $\alpha$, in contrast to a positive correlation with $\mathrm{TNF} \alpha$ mRNA expression in subcutaneous adipose tissue. The limited number of patients and interaction of many complex regulations during the surgery should be taken into consideration in interpreting these findings.

Unfortunatelly, serum hepcidin concentrations were not measured. On the other hand, we could not simply deduce from hepcidin serum concentration its expression in different tissues and their contribution to its systemic effects. In contrast to adipose tissue, hepcidin expression in the liver reacts not only to inflammation but also to iron metabolism, anemia and erythropoiesis. Adipose tissue is not the main organ of hepcidin production but according to our data, it could - due to large amount of body fat - influence hepcidin systemic levels in case of inflammation within few hours.

Ferroportin mRNA expression decreased during the surgery. The increase of TfR 1 mRNA expression could be due to activation of adipose tissue during acutephase reaction. The changes of DMT1 and ferritin were less consistent.

In summary, this study demonstrated that acute stress induced by cardiac surgery in humans significantly increases subcutaneous but not epicardial hepcidin mRNA expression. It remains to be determined the quantitative significance of hepcidin production in adipose tissue when compared to the liver and the possibilites of other specific roles of hepcidin within the adipose tissue.

\section{Conflict of Interest}

There is no conflict of interest.

\section{Acknowledgements}

This work was supported by grants MSM 0021620806 , MSM 0021620807, LC 06044 from the Ministry of Education of the Czech Republic, MZOVFN2005 and NS10300-3 from MZ CR. The technical assistance of Ms. Alena Revinová is gratefully acknowledged.

\section{References}

ADAMSON JW: The anemia of inflammation/malignancy: mechanisms and management. Hematology Am Soc Hematol Educ Program 2008: 159-165, 2008.

AUSK KJ, IOANNOU GN: Is obesity associated with anemia of chronic disease? A population-based study. Obesity (Silver Spring) 16: 2356-2361, 2008.

BEKRI S, GUAL P, ANTY R, LUCIANI N, DAHMAN M, RAMESH B, IANNELLI A, STACCINI-MYX A, CASANOVA D, BEN AMOR I, SAINT-PAUL MC, HUET PM, SADOUL JL, GUGENHEIM J, SRAI SK, TRAN A, MARCHAND-BRUSTELY: Increased adipose tissue expression of hepcidin in severe obesity is independent from diabetes and NASH. Gastroenterology 131: 788-796, 2006.

BENDINELLI P, MARONI P, PECORI GIRALDI F, PICCOLETTI R: Leptin activates Stat3, Stat1 and AP-1 in mouse adipose tissue. Mol Cell Endocrinol 168: 11-20, 2000.

CHUNG B, MATAK P, MCKIE AT, SHARP P: Leptin increases the expression of the iron regulatory hormone hepcidin in HuH7 human hepatoma cells. J Nutr 137: 2366-2370, 2007.

CORWIN HL, KRANTZ SB: Anemia of the critically ill: "acute" anemia of chronic disease. Crit Care Med 28: 30983099, 2000.

CREELY SJ, MCTERNAN PG, KUSMINSKI CM, FISHER M, DA SILVA NF, KHANOLKAR M, EVANS M, HARTE AL, KUMAR S: Lipopolysaccharide activates an innate immune system response in human adipose tissue in obesity and type 2 diabetes. Am J Physiol 292: E740-E747, 2007.

DANDONA P, ALJADA A, BANDYOPADHYAY A: Inflammation: the link between insulin resistance, obesity and diabetes. Trends Immunol 25: 4-7, 2004. 
FLEMING MD: The regulation of hepcidin and its effects on systemic and cellular iron metabolism. Hematology Am Soc Hematol Educ Program 2008: 151-158, 2008.

GANZ T: Molecular control of iron transport. J Am Soc Nephrol 18: 394-400, 2007.

HALUZÍK M, PAŘÍZKOVÁ J, HALUZÍK MM: Adiponectin and its role in the obesity-induced insulin resistance and related complications. Physiol Res 53: 123-129, 2004.

HAVEL PJ: Control of energy homeostasis and insulin action by adipocyte hormones: leptin, acylation stimulating protein, and adiponectin. Curr Opin Lipidol 13: 51-59, 2002.

HOPPE M, LONNERDAL B, HOSSAIN B, OLSSON S, NILSSON F, LUNDBERG PA, RODJER S, HULTHEN L: Hepcidin, interleukin- 6 and hematological iron markers in males before and after heart surgery. $J$ Nutr Biochem 20: 11-16, 2009.

HOTAMISLIGIL GS: Inflammation and metabolic disorders. Nature 444: 860-867, 2006.

KEMNA EH, KARTIKASARI AE, VAN TITS LJ, PICKKERS P, TJALSMA H, SWINKELS DW: Regulation of hepcidin: insights from biochemical analyses on human serum samples. Blood Cells Mol Dis 40: 339-346, 2008a.

KEMNA EH, TJALSMA H, WILLEMS HL, SWINKELS DW: Hepcidin: from discovery to differential diagnosis. Haematologica 93: 90-97, 2008b.

KŘEMEN J, DOLÍNKOVÁ M, KRAJIČCOVÁ J, BLÁHA J, ANDERLOVÁ K, LACINOVÁ Z, HALUZÍKOVÁ D, BOŠANSKÁ L, VOKURKA M, SVAČINA S, HALUZÍK M: Increased subcutaneous and epicardial adipose tissue production of proinflammatory cytokines in cardiac surgery patients: possible role in postoperative insulin resistance. J Clin Endocrinol Metab 91: 4620-4627, 2006.

KRIJT J, CMEJLA R, SÝKORA V, VOKURKA M, VYORAL D, NEČAS E: Different expression pattern of hepcidin genes in the liver and pancreas of C57BL/6N and DBA/2N mice. $J$ Hepatol 40: 891-896, 2004.

KRIJT J, NIEDERKOFLER V, SALIE R, ŠEFC L, PELICHOVSKÁ T, VOKURKA M, NEČAS E: Effect of phlebotomy on hepcidin expression in hemojuvelin-mutant mice. Blood Cells Mol Dis 39: 92-95, 2007.

KULAKSIZ H, FEIN E, REDECKER P, STREMMEL W, ADLER G, CETIN Y: Pancreatic beta-cells express hepcidin, an iron-uptake regulatory peptide. $J$ Endocrinol 197: 241-249, 2008.

LIN L, GOLDBERG YP, GANZ T: Competitive regulation of hepcidin mRNA by soluble and cell-associated hemojuvelin. Blood 106: 2884-2889, 2005.

MARUNA P, LINDNER J, KUNŠTÝŘ J, PLOCOVÁ K, HUBÁČEK J: Plasma prohepcidin as a negative acute phase reactant after large cardiac surgery with a deep hypothermic circulatory arrest. Physiol Res 58: 827-833, 2009.

MCCLUNG JP, KARL JP: Iron deficiency and obesity: the contribution of inflammation and diminished iron absorption. Nutr Rev 67: 100-104, 2009.

MENZIE CM, YANOFF LB, DENKINGER BI, MCHUGH T, SEBRING NG, CALIS KA, YANOVSKI JA: Obesityrelated hypoferremia is not explained by differences in reported intake of heme and nonheme iron or intake of dietary factors that can affect iron absorption. $J$ Am Diet Assoc 108: 145-148, 2008.

MERLE U, FEIN E, GEHRKE SG, STREMMEL W, KULAKSIZ H: The iron regulatory peptide hepcidin is expressed in the heart and regulated by hypoxia and inflammation. Endocrinology 148: 2663-2668, 2007.

NEMETH E, VALORE EV, TERRITO M, SCHILLER G, LICHTENSTEIN A, GANZ T: Hepcidin, a putative mediator of anemia of inflammation, is a type II acute-phase protein. Blood 101: 2461-2463, 2003.

NICOLAS G, CHAUVET C, VIATTE L, DANAN JL, BIGARD X, DEVAUX I, BEAUMONT C, KAHN A, VAULONT S: The gene encoding the iron regulatory peptide hepcidin is regulated by anemia, hypoxia, and inflammation. J Clin Invest 110: 1037-1044, 2002.

PAK M, LOPEZ MA, GABAYAN V, GANZ T, RIVERA S: Suppression of hepcidin during anemia requires erythropoietic activity. Blood 108: 3730-3735, 2006.

PARK CH, VALORE EV, WARING AJ, GANZ T: Hepcidin, a urinary antimicrobial peptide synthesized in the liver. J Biol Chem 276: 7806-7810, 2001.

PIGEON C, ILYIN G, COURSELAUD B, LEROYER P, TURLIN B, BRISSOT P, LOREAL O: A new mouse liverspecific gene, encoding a protein homologous to human antimicrobial peptide hepcidin, is overexpressed during iron overload. J Biol Chem 276: 7811-7819, 2001.

SONDERGAARD L: Homology between the mammalian liver and the Drosophila fat body. Trends Genet 9: 193, 1993. 
SOW FB, FLORENCE WC, SATOSKAR AR, SCHLESINGER LS, ZWILLING BS, LAFUSE WP: Expression and localization of hepcidin in macrophages: a role in host defense against tuberculosis. J Leukoc Biol 82: 934-945, 2007.

THEURL I, THEURL M, SEIFERT M, MAIR S, NAIRZ M, RUMPOLD H, ZOLLER H, BELLMANN-WEILER R, NIEDEREGGER H, TALASZ H, WEISS G: Autocrine formation of hepcidin induces iron retention in human monocytes. Blood 111: 2392-2399, 2008.

TONG Q, DALGIN G, XU H, TING CN, LEIDEN JM, HOTAMISLIGIL GS: Function of GATA transcription factors in preadipocyte-adipocyte transition. Science 290: 134-138, 2000.

VERGA FALZACAPPA MV, MUCKENTHALER MU: Hepcidin: iron-hormone and anti-microbial peptide. Gene 364: 37-44, 2005.

VERGA FALZACAPPA MV, VUJIC SPASIC M, KESSLER R, STOLTE J, HENTZE MW, MUCKENTHALER MU: STAT3 mediates hepatic hepcidin expression and its inflammatory stimulation. Blood 109: 353-358, 2007.

VOKURKA M, KRIJT J, SULC K, NECAS E: Hepcidin mRNA levels in mouse liver respond to inhibition of erythropoiesis. Physiol Res 55: 667-674, 2006.

WEINSTEIN DA, ROY CN, FLEMING MD, LODA MF, WOLFSDORF J, ANDREWS NC: Inappropriate expression of hepcidin is associated with iron refractory anemia: implications for the anemia of chronic disease. Blood 100: 3776-3781, 2002.

WEISS G,. GOODNOUGH LT: Anemia of chronic disease. N Engl J Med 352: 1011-1023, 2005.

WENZEL BJ, STULTS HB, MAYER J: Hypoferraemia in obese adolescents. Lancet 2: 327-328, 1962.

WRIGHTING DM, ANDREWS NC: Interleukin-6 induces hepcidin expression through STAT3. Blood 108: $3204-$ 3209, 2006.

YANOFF LB, MENZIE CM, DENKINGER B, SEBRING NG, MCHUGH T, REMALEY AT, YANOVSKI JA: Inflammation and iron deficiency in the hypoferremia of obesity. Int J Obes (Lond) 31: 1412-1419, 2007.

ZIMMERMANN MB, ZEDER C, MUTHAYYA S, WINICHAGOON P, CHAOUKI N, AEBERLI I, HURRELL RF: Adiposity in women and children from transition countries predicts decreased iron absorption, iron deficiency and a reduced response to iron fortification. Int J Obes (Lond) 32: 1098-1104, 2008. 